\section{P.E.R}

Pioneer in peer-reviewed, open access online law publications

Author

Malcolm Wallis

Affiliation

University of KwaZulu-Natal South Africa

Email mjdwallis@gmail.com

Date Submission

4 October 2019

Date Revised

9 October 2019

Date Accepted

9 October 2019

Date published

25 October 2019

Guest Editor Prof W le Roux

How to cite this article

Wallis M "Interpretation Before and After Natal Joint Municipal Pension Fund $v$ Endumeni Municipality 20124 SA 593 (SCA)" PER / PELJ 2019(22) - DOI

http://dx.doi.org/10.17159/1727-

3781/2019/v22i0a7416

Copyright

DOI

http://dx.doi.org/10.17159/1727-

3781/2019/v22i0a7416

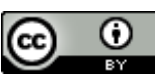

\begin{abstract}
This article explores the background to the decision in Natal Joint Municipal Pension Fund v Endumeni Municipality 20124 SA 593 (SCA), some of its conceptual content and its broader implications for future jurisprudence in regard to the interpretation of documents. It illustrates the reality that in the past interpretation in different areas of the law was undertaken in accordance with differing standards even though all areas involved the interpretation of language in common everyday use, and questions the need to approach issues of interpretation in a way different from that used in conventional language. The internal inconsistencies of past authority are highlighted, as well as the trend in South African jurisprudence and overseas towards a single, simple and coherent approach to interpretation. The importance of recognising the role of both text and context is stressed, and the identification of relevant context in interpreting contracts and statutes is addressed. The article identifies two animating principles underlying the approach to interpretation in Endumeni, viz.: the discipline it imposes on judges to explain their decisions in regard to interpretation rather than starting with an a priori meaning and buttressing it with authority, and the desirability of a single, clear and simple standard by which to approach issues of interpretation.
\end{abstract}

\section{Keywords}

Endumeni; background; effect; interpretation; text; context; objective iterative process; context; sensible construction. 


\section{Introduction}

When I was a law student our curriculum outwardly included only one course dealing with interpretation, that being "Interpretation of Statutes", where our text was Steyn's Uitleg van Wette, then in its third or fourth edition. The rule, so we were told, was that statutes should be given their literal meaning, but that courts could depart from this if the literal meaning would result in an absurdity. In a country where much of the legislation affecting the population seemed absurd, this was difficult to comprehend, even in those far-off times.

The curriculum's outward appearance that interpretation related to statutes alone was misleading. In the course on contract we were introduced to what appeared to be a different rule, that contracts should be interpreted in accordance with the intention of the parties and the plain meaning of the words in the contract. To this was added the rider that evidence of the negotiations between the parties and, if they had taken the precaution of reducing their contract to writing, parol (which meant oral, although no-one told us that) evidence of their intentions, was strictly inadmissible. Nothing was said about the vagaries of interpreting oral contracts as opposed to written ones.

In case this confusion was insufficient, the law of succession involved an extensive foray into the rules for the construction of wills, where we were sent in search of the intention of the testator and warned of the shades of testators long dead who awaited us when we disappointed their expectations. Fortunately, being only students, we were not taken to the niceties of construing patent specifications or judgments. Those were delights that still awaited us.

The subject that we did not discuss was why our interpretation and understanding of legal documents of any type was, or should be, any different from the approach that we habitually adopted to other documents couched in a language with which all of us were familiar. Part of our daily existence involved reading books, newspapers, magazines, journals of

Malcolm Wallis. B Com LLB (Natal) PhD (UKZN). SC, Judge of the Supreme Court of Appeal, Honorary Professor of Law in the University of KwaZulu-Natal, South Africa. E-mail: mjdwallis@gmail.com. I am grateful to Nondumiso Phenyane and Dimakatso Ramaisa, both researchers at the SCA, and Amy Sinclair, an intern researcher at the SCA, for their research assistance and input in relation to the first draft of this article. Responsibility for it is mine alone. The article is a revised version of an address given at the University of the Western Cape on 23 March 2018 as the keynote address at a conference on legal interpretation. 
varying types and other expressions of the written word. We approached all of those with little need for special rules of interpretation to enlighten us as to their meaning. Of course, we were well aware of ambiguity of meaning, the pitfalls arising from the misuse of language and the different character of different texts. No instruction was necessary in order for us to understand that a dictionary was different from a novel, or that a textbook sought to convey information and thoughts with a degree of precision absent from a newspaper or popular magazine. Yet as law students all this went by the board and we were inducted into the mysteries of legal interpretation.

\section{Rules and reality}

Trying to apply these rules of interpretation in courts over many years as an advocate proved troublesome and the rules seemed more fluid and less certain in their application the longer I practised. This can be illustrated by way of two examples. Recently, while taking some of the SCA researchers on a tour of the court, one asked whether I remembered my first appearance there. I did, ${ }^{1}$ and it was about a question of law reserved in a criminal appeal on the meaning of the definition of "aggravating circumstances" under the Criminal Procedure Act. ${ }^{2}$ My client had been convicted of robbery with aggravating circumstances, where the victim of the robbery had been threatened with a knife during the robbery. The problem was that there were two accused and the State could not show which one produced the knife or whether the other robber even knew that his partner in crime had a knife. So there was no common purpose in regard to the aggravating circumstances.

After the initial insertion of the definition into the Act, Schreiner JA doubted whether the doctrine of common purpose could be invoked to justify a finding of aggravating circumstances, or whether such circumstances had to be found individually for each accused. ${ }^{3}$ This prompted an amendment to the definition, which, the Minister of Justice explained in parliament, was intended to make it clear that the doctrine of common purpose could be used to make a finding of aggravating circumstances. Thereafter in Cain the Appellate Division held that Schreiner JA's doubts in regard to the original definition were misplaced, ${ }^{4}$ thereby rendering the amendment unnecessary. In my case the trial judge used the amendment to justify the conclusion that

S v Dhlamini 19741 SA 90 (A).

Then Criminal Procedure Act 56 of 1955, but the same definition appears in s 1(1)(b) of the Criminal Procedure Act 51 of 1977.

$R v$ Sisilane $19582 \mathrm{SA} 448$ (A) 451H, 453G.

$R v$ Cain 19593 SA 376 (A) 381. 
if aggravating circumstances were present in respect of any one accused, all of them should be found guilty of robbery with aggravating circumstances, even though there was no common purpose in regard to the aggravating circumstance. Whether he was correct was the question of law.

Although I had read it, I was not permitted in argument to refer to the Minister's speech, because at the time (and possibly still) that was inadmissible. I submitted that the sole purpose of the amendment was to resolve Schreiner JA's doubts, which had in any event been dispelled by Cain. This was rejected and the court held that the plain meaning, and the intention of the legislature, in the amended section was that conduct constituting an aggravating circumstance on the part of one of the accused required a finding of aggravating circumstances against all of the accused, even if they lacked common purpose in relation to the aggravating circumstance. The result was that an amendment to ensure that common purpose applied to findings of aggravated circumstances resulted in a judgment that it was inapplicable and unnecessary. ${ }^{5}$ That had serious implications because robbery with aggravating circumstances carried with it a potential death penalty, and it now carries with it a minimum sentence of 15 years imprisonment in the absence of substantial and compelling circumstances warranting a lower sentence. The application of the plain meaning rule and the endeavour to ascertain the intention of the legislature resulted in the court arriving at a conclusion diametrically opposite to that intended by parliament.

This was an introduction to the potentially unjust effect of applying the rules of interpretation that I had been taught, but belief that the plain meaning rule would always prevail was dispelled in a subsequent appeal that I argued. ${ }^{6}$ It involved a contract for the construction of civil works and the amount to be paid to the contractor. A clause in the contract provided that: ${ }^{7}$

... if the net effect of all variations as valued ... shall be found on completion of the whole of the works to have resulted in a reduction or an addition greater

5 Sadly, when the Constitutional Court was afforded the opportunity of remedying this fundamental affront to the basic principles of criminal liability it endorsed the finding in Dhlamini and held that it was constitutionally compliant. Minister of Justice and Constitutional Development v Masingili 20141 SACR 437 (CC). The rule against the admissibility of parliamentary materials has (controversially) been abolished in England (Pepper v Hart [1993] 1 All ER $42(\mathrm{HL})$ ), but not yet authoritatively in South Africa ( $S$ v Makwanyane 19953 SA 391 (CC) paras 14 and 15). However, there is no indication that the Constitutional Court examined, or gave any consideration to examining, the parliamentary material before deciding Masingili.

$6 \quad$ Melmoth Town Board v Marius Mostert (Pty) Ltd 19843 SA 718 (AD).

7 Melmoth Town Board v Marius Mostert (Pty) Ltd 19843 SA 718 (AD) 726 C-D. Emphasis added. 
than 15 per cent of the sum named in the tender ... the amount of the contract price shall be further increased or decreased by such sum (if any) as in the opinion of the engineer shall be reasonable ....

There had been an addition to the contract price of more than 15 per cent, but the engineer had tried to reduce the contract price, not increase it. I was for the contractor and, pardon the pun, the plain meaning rule was plainly on my side. If there had been a reduction or addition to the tender price greater than 15 per cent, the contract price was to be "further increased or decreased". On any usage of the English language something can only be "further increased" if it has already been increased, and it can only be further decreased if it has already gone down. Undeterred by such niceties, the court ignored the word "further" and held that the "manifest purpose of the clause was to enable the engineer to adjust the price either upwards or downwards", largely because it couldn't imagine why the person who drafted the clause would have imposed such a limitation on the engineer. The obvious reason that the drafter was not as clever or imaginative as the members of the appeal court did not occur to them. It was some consolation that I nevertheless won the appeal on a different point.

There were reasons therefore for being a little cynical about suggestions that words are to be given "their ordinary grammatical meaning", 8 or that the intention of the parties or the legislature is to be sought and respected. ${ }^{9}$ Experience taught that this was not how judges and courts went about the process of interpretation, whether of contracts or statutes. So, when in Coopers \& $L y b r a n d^{10}$ the proper approach to interpretation was summarised as being that one should first "ascertain the literal meaning of the words" and thereafter have regard to context and background circumstances, applying extrinsic evidence of surrounding circumstances when

An idea drawn from Lord Wensleydale's oft-cited Golden Rule (Grey $v$ Pearson $6 \mathrm{H}$ L Cas 106) that: "In construing wills and, indeed statutes and all written instruments, the grammatical and ordinary sense of the words is to be adhered to, unless that would lead to some absurdity, or some repugnancy or inconsistency with the rest of the instrument." Principal Immigration Officer v Hawabu 1936 AD 26 31; Crispette and Candy Co Ltd $v$ Oscar Michaleis and Leopold Alexander Michaelis 19474 SA 521 (A) 543; Kalil v Standard Bank of South Africa Ltd 19674 SA 550 (A) 556C-E. The proposition is still occasionally mentioned, but almost inevitably followed by a reference to the importance of context. Cool Ideas 1186 CC v Hubbard 20144 SA 474 (CC) (hereafter the Cool Ideas case) para 28. I am not alone in my cynicism, see Jansen 1981 TSAR 102-103. See, for example, the convoluted endeavor to explain the plain meaning in accordance with the intention of the legislature in Summit Industrial Corporation $v$ Claimants against the Fund Comprising the Proceeds of the Sale of the MV Jade Transporter 19872 SA 583 (A) 595I-596F. case) 768 A-E. 
encountering ambiguity, courts were being asked to engage in an artificial process. That is not how human beings read documents or seek to understand their meaning. Nor was it the way in which judges interpreted statutes or contracts.

Let me give an example. When a passing motorist sees a newspaper poster proclaiming "BULLS GORE SHARKS", their understanding does not start with their thinking that literally it means that male bovines somehow encountered a school of aquatic animals and savaged them with their horns. Nor would our hypothetical motorist then examine context, of which there would be precious little in relation to a newspaper poster displayed on a lamppost, and conclude that the literal meaning is absurd so that they could resort to extrinsic evidence of surrounding circumstances to discern its meaning. I venture to suggest that the vast majority of South Africans would read it and understand instantly that it referred to the result of a game of rugby. But that would be because from the outset they factored into their understanding the whole of the relevant context - the nature and purpose of the poster, the day of its appearance after a weekend, interest in the game of rugby and their own knowledge of the local participants in the game.

\section{The path to Endumeni ${ }^{11}$}

Coopers \& Lybrand was itself internally inconsistent. It cited ${ }^{12}$ the judgment in Cape Fabrix, ${ }^{13}$ where Rumpff CJ said that words should not be clipped out of the document and placed on a clean piece of paper and their meaning determined, but that they should be examined in the light of the nature and purpose of the document and their situation in the document as a whole. Having quoted that very passage, Joubert JA went on immediately thereafter to say that looking at the context should occur "after having ascertained the literal meaning of the word or phrase in question". Which was it to be? The answer was opaque, if any answer was to be found.

All of this illustrated the tug of war that had gone on for many years between literalists and contextual interpreters and identified by Schreiner JA in Jaga $v$ Dönges. ${ }^{14}$ There can be little surprise that, after the decision in Coopers $\&$ Lybrand, the case law went back and forth between these two poles. The

\footnotetext{
$11 \quad$ Natal Joint Municipal Pension Fund v Endumeni Municipality 20124 SA 593 (SCA) (hereafter the Edumeni case).

Coopers \& Lybrand 767I-J.

Swart v Cape Fabrix (Pty) Ltd 19791 SA 195 (A) 202C.

Jaga v Dönges; Bhana v Dönges 19504 SA 653 (A) 662G-663A.
} 
result was an absence of clarity about the process of interpretation and judgments became something of a "pick and mix" selection, where judges could find authority supporting whatever approach they wished to take in a case. So Judge A would find the wording clear and say that the context was irrelevant and inadmissible - citing copious authority for that stance - while Judge $B$ would find the same language hopelessly confused and resort to context in order to resolve the confusion - likewise citing copious authority in support of that approach. Even more confusingly, one could find cases where two judges adopted the plain meaning approach, but contradicted one another on what that plain meaning was. ${ }^{15}$

This type of confusion was manifestly undesirable. There is an obvious advantage - save possibly for those with ambitions to write books on contractual or statutory interpretation - to courts having a single reasonably clear standard by which to approach questions of interpretation, without the need to trawl through a mountain of inconsistent judgments and dicta. Far from settling matters, Coopers \& Lybrand exacerbated the problems and led to further attempts to make sense of nearly a century of unruly and inconsistent authorities in which courts endeavoured to clarify the meaning of "intention of the parties (or legislature)", "plain meaning of words", "context", "surrounding circumstances", or the English derivative "the matrix of facts". 16 The dam broke initially in that most technical of fields, the construction of patent specifications, ${ }^{17}$ and then in other cases in the SCA, ${ }^{18}$ of which I single out in particular KPMG $v$ Securefin. Of course, encouragement came from the Constitutional Court. ${ }^{19}$ So when it came to

15 Compare the judgment of Heher AJA with the judgment in the court below in Van der Westhuizen v Arnold 20026 SA 453 (SCA) paras 8 and 9. The judgment of Lewis AJA agreed with the result in the court below, but on the basis that the language was unclear and that contextual considerations dictated the outcome. Marais JA appears to have taken the view that the plain meaning was something different from that espoused by Heher AJA, although he did not endorse the expansive approach of Lewis AJA.

Prenn v Simmons [1971] 3 All ER 237 (HL) 239. Cited with approval in Swart v Cape Fabrix (Pty) Ltd 19791 SA 195 (A) 201F and Nederduitse Gereformeerde Kerk in Afrika (OVS) v Verenigende Gereformeerde Kerk in Suider-Afrika 19992 SA 156 (SCA) 167B-D.

$17 \quad$ Aktiebolaget Hässle $v$ Triomed (Pty) Ltd 20031 SA 155 (SCA) paras 8 and 9.

18 Bastian Financial Services (Pty) Ltd $v$ General Hendrik Schoeman Primary School 20085 SA 1 (SCA) paras 16-19; Masstores (Pty) Ltd v Murray \& Roberts Construction (Pty) Ltd 20086 SA 654 (SCA) para 7; KPMG Chartered Accountants (SA) v Securefin Ltd 20094 SA 399 (SCA) para 39; Ekurhuleni Metropolitan Municipality $v$ Germiston Municipal Retirement Fund 20102 SA 498 (SCA) paras 12-14.

19 Bato Star Fishing (Pty) Ltd v Minister of Environmental Affairs 20044 SA 490 (CC) para 90; Department of Land Affairs v Goedgelegen Tropical Fruits (Pty) Ltd 20076 
Endumeni the groundwork had been laid to essay a general statement of where our courts had arrived when it came to the approach to the interpretation of documents.

In that sense commentators who say that Endumeni is not an earthquake rearranging the tectonic plates of the interpretation of documents are correct. Like Lord Hoffmann's summary in $I C S^{20}$ it is rather more an endeavour to identify where the slowly shifting, grinding together of those tectonic plates has taken us. ${ }^{21}$ But that the configuration of the landscape is now different and that Coopers \& Lybrand has properly been consigned to the history books 22 is undeniable. That is apparent to anyone whose daily work is in the courts, where lengthy excursuses on statutory or contractual interpretation have given way to the citation of the summaries in Endumeni and Bothma-Batho, both in judgments and in heads of argument. I am conscious that, like Touchstone's ungallant comment about his wife, ${ }^{23}$ Endumeni is "an ill-favoured thing, but mine own". Nonetheless my sense is that judges and counsel alike cite it with a sigh of relief in the belief that it enables them to get on with arguing or dealing with the issues that really concern the litigants. ${ }^{24}$ Its recent endorsement by the Constitutional Court should serve to emphasise that trend. ${ }^{25}$

\section{Others tread the same path}

The gradual shift away from a literal process of interpreting contracts and statutes to one where both text and context have a role to play is not confined to the UK and South Africa. The UK was perhaps in the forefront in the field of contractual interpretation with judgments such as Prenn $v$

SA 199 (CC) para 52. On its face the summary in Cool Ideas para 28 appears to be a retrograde step from this perspective, but I doubt that this was intended. Investors Compensation Scheme Ltd v West Bromwich Building Society (hereafter the ICS case) [1998] 3 All ER 98 (HL) 114-115.

21 A view shared by my colleague Lewis JA in Novartis SA (Pty) Ltd v Maphil Trading (Pty) Ltd 20161 SA 518 (SCA) para 28. She also concurred in my judgment in Bothma-Batho Transport (Edms) Bpk v S Bothma \& Seun Transport (Edms) Bpk 20142 SA 494 (SCA) (hereafter the Bothma-Batho case).

22 Bothma-Batho paras 11 and 12.

23 Shakespeare As You Like It Act 5, Scene 4.

24 A search by one of the researchers at the SCA revealed that the Constitutional Court has cited it with approval on 16 occasions, often in conjunction with Cool ldeas, as well as 50 decisions of the SCA, and a number of decisions in the High Court and the Labour Court. (CC) para 29. 


\section{Simmons ${ }^{26}$ and $I C S .{ }^{27}$ The approach in those cases has not been expressly endorsed in the field of statutory interpretation, but the differences between the two seem small as appears from Lord Bingham's speech in Quintavalle:28}

Such is the skill of parliamentary draftsmen that most statutory enactments are expressed in language which is clear and unambiguous and gives rise to no serious controversy. But these are not the provisions which reach the courts, or at any rate the appellate courts. Where parties expend substantial resources arguing about the effect of a statutory provision it is usually because the provision is, or is said to be, capable of bearing two or more different meanings, or to be of doubtful application to the particular case which has now arisen, perhaps because the statutory language is said to be inapt to apply to it, sometimes because the situation which has arisen is one which the draftsman could not have foreseen and for which he has accordingly made no express provision.

The basic task of the court is to ascertain and give effect to the true meaning of what Parliament has said in the enactment to be construed. But that is not to say that attention should be confined and a literal interpretation given to the particular provisions which give rise to difficulty. Such an approach not only encourages immense prolixity in drafting, since the draftsman will feel obliged to provide expressly for every contingency which may possibly arise. It may also (under the banner of loyalty to the will of Parliament) lead to the frustration of that will, because undue concentration on the minutiae of the enactment may lead the court to neglect the purpose which Parliament intended to achieve when it enacted the statute. Every statute other than a pure consolidating statute is, after all, enacted to make some change, or address some problem, or remove some blemish, or effect some improvement in the national life. The court's task, within the permissible bounds of interpretation, is to give effect to Parliament's purpose. So the controversial provisions should be read in the context of the statute as a whole, and the statute as a whole should be read in the historical context of the situation which led to its enactment.

The same trend can be seen elsewhere. In Rizzo ${ }^{29}$ the Supreme Court of Canada approved the following statement of principle in respect of statutory interpretation:

Today there is only one principle or approach, namely, the words of an Act are to be read in their entire context and in their grammatical and ordinary sense harmoniously with the scheme of the Act, the object of the Act, and the intention of Parliament. ${ }^{30}$ ER $98(\mathrm{HL})$. 
A broadly similar approach to the construction of contracts has also emerged in that jurisdiction, as courts have moved away from concepts of the plain meaning and technical rules of construction. The Supreme Court of Canada expressed this in Sattva Capita ${ }^{1}$ in the following terms:

Regarding the first development, the interpretation of contracts has evolved towards a practical, common-sense approach not dominated by technical rules of construction. The overriding concern is to determine 'the intent of the parties and the scope of their understanding'. To do so, a decision-maker must read the contract as a whole, giving the words used their ordinary and grammatical meaning, consistent with the surrounding circumstances known to the parties at the time of formation of the contract. Consideration of the surrounding circumstances recognizes that ascertaining contractual intention can be difficult when looking at words on their own, because words alone do not have an immutable or absolute meaning: 'No contracts are made in a vacuum: there is always a setting in which they have to be placed. ... In a commercial contract it is certainly right that the court should know the commercial purpose of the contract and this in turn presupposes knowledge of the genesis of the transaction, the background, the context, the market in which the parties are operating.' The meaning of words is often derived from a number of contextual factors, including the purpose of the agreement and the nature of the relationship created by the agreement. ... As stated by Lord Hoffmann in Investors Compensation Scheme Ltd. v. West Bromwich Building Society, [1998] 1 All E.R. 98 (H.L.): 'The meaning which a document (or any other utterance) would convey to a reasonable man is not the same thing as the meaning of its words. The meaning of words is a matter of dictionaries and grammars; the meaning of the document is what the parties using those words against the relevant background would reasonably have been understood to mean.'

A voyage to other countries leads to similar articulations of principle. In a 2016 lecture, Justice Middleton of the Federal Court of Australia said: ${ }^{2}$

Undoubtedly, there is a need for readily understandable and consistent principles to guide the interpretation of legislation. These principles should basically be guided by common sense and we should not be blinded by too many rules, over-analysis, or mechanical or scientific analysis. Trawling for rules and canons of interpretation is not the correct starting point. The starting point should always be to look at the words, their context, and the purpose of the legislation, then applying that to produce a result that is both fair and workable in the particular fact situation you have before you.

Earlier adherence to the more traditional approach in regard to contractual interpretation ${ }^{33}$ - one that resonates with the judgment in Coopers \& Lybrand

31 Sattva Capital Corporation (Formerly Sattva Capital Inc v Cresston Moby Corporation (Formerly George Ventures Inc) [2014] SCR 633 paras 47 and 48 . See aAlso see para 50 . Sources omitted.

32 Middleton 2016 http://www.fedcourt.gov.au/digital-law-library/judges-speeches/ justice-middleton/middleton-j-20160414.

33 Codelfa Construction Pty Ltd v State Rail Authority of New South Wales (1982) 149 CLR 337352. 
- has given way to one where the approach to contracts and statutes is the same. ${ }^{34}$ In Byrnes $v$ Kendle ${ }^{35}$ it was said:

The approach taken to statutory construction is matched by that which is taken to contractual construction. Contractual construction depends on finding the meaning of the language of the contract - the intention which the parties expressed, not the subjective intentions which they may have had, but did not express. A contract means what a reasonable person having all the background knowledge of the 'surrounding circumstances' available to the parties would have understood them to be using the language in the contract to mean.

Other jurisdictions applying English common law have followed Lord Hoffmann's approach in ICS. This is true in New Zealand, ${ }^{36}$ which also applies a purposive approach to the interpretation of statutes in the light of the text of the legislation and its purpose. ${ }^{37}$ Singapore follows suit with a statutory requirement that statutes be given a purposive interpretation and a contextual approach to contracts derived from England and the judgment in ICS. ${ }^{38}$ Malaysia does so also with a statutory obligation to give legislation a purposive construction and the same contextual approach to contracts. ${ }^{39}$ Unsurprisingly Hong Kong has followed the route of ICS in a judgment of

Justice Robert McDougall Construction of Contracts: The High Court's Approach, paper delivered to the Commercial Law Association Judges on 26 June 2015 (McDougall

http://www.supremecourt.justice.nsw.gov.au/Documents/Publications/Speeches/20 15\%20Speeches/McDougall_20150626.pdf). The paper highlights nine judgments in which the approach of the High Court has moved in the same direction as South Africa and the United Kingdom, although it has not expressly disavowed Codelfa. See Western Export Services Inc v Jireh International Pty Ltd (2011) 282 ALR 804 (HCA). See aAlso see Spigelman 2007 ALJ 322. Byrnes v Kendle (2011) 243 CLR 253 para 98. See also Electricity Generation Corporation v Woodside Energy Ltd 251 CLR 640 (HCA) para 35.

36 Firm PI 1 Ltd v Zurich Australian Insurance Ltd [2015] NZLR 432 para 60. One judge, Tipping $\mathrm{J}$, has gone further and held that evidence of pre-contractual negotiations is admissible in the process of interpretation. See Vector Gas Ltd $v$ Bay of Plenty Energy Ltd [2010] 2 NZLR 444 para 19 and Barber 2016 VUWLR 227. This goes further than is permitted in the UK. Chartbrook Ltd v Persimmon Homes Ltd [2009] UKHL 38.

37 Section 5(1) of the New Zeeland Interpretation Act 85 of 1999 and see Glazebrook 2003 https://www.courtsofnz.govt.nz/speechpapers/Speech05-05-2003.pdf.

Section 9A of the Singapore Interpretation Act 10 of 1965 as amended in 1993 and the address by Menon CJ entitled The Interpretation of Documents: Saying what they Mean or Meaning what they Say (Menon 2013 http://www.supremecourt.gov.sg/docs/default-source/default-documentlibrary/sjc/the-interpretation-of-documents---saying-what-they-mean-or-meaningwhat-they-say.pdf). As to contracts see Zurich Insurance (Singapore) Pte Ltd v BGold Interior Design \& Construction Pte Ltd [2008] 3 SLR (R) 1029. gid $=2705$. 
Lord Hoffmann sitting in the Hong Kong Court of Final Appeal. ${ }^{40}$ In regard to statutes, its approach is deliberately purposive and contextual. ${ }^{41}$

The task of the academic community is similar to that of the tell-tales builders and engineers use to identify movement in buildings. Academics look to identify every faint hint of movement in the law. They parse the language of judgments (often in a very literal way) to sense where shifts in the law are occurring. In the field of interpretation there have been some suggestions that in the United Kingdom there has been a movement away from Lord Hoffmann back to the former position of giving far greater weight to the natural meaning of the words used in a contract. ${ }^{42}$ The shift was perceived to have occurred in Arnold $v$ Britton, ${ }^{43}$ where it was suggested that the Supreme Court had moved away from Lord Hoffmann's approach in ICS, as approved in Rainy Sky, ${ }^{44}$ and reverted to a more literal reading of contracts. However, in Wood $v$ Capita Insurance, ${ }^{45}$ the Supreme Court decisively shot down these suggestions. In para 13 Lord Hodge said:

Textualism and contextualism are not conflicting paradigms in a battle for exclusive occupation of the field of contractual interpretation. Rather, the lawyer and the judge, when interpreting any contract, can use them as tools to ascertain the objective meaning of the language which the parties have chosen to express their agreement. The extent to which each tool will assist the court in its task will vary according to the circumstances of the particular agreement or agreements. Some agreements may be successfully interpreted principally by textual analysis, for example because of their sophistication and complexity and because they have been negotiated and prepared with the assistance of skilled professionals. The correct interpretation of other

$40 \quad$ Jumbo King Ltd v Faithful Properties Ltd (1999) 3 HKLRD 757 (CFA) para 59 and Fully Profit (Asia) Ltd v Secretary for Justice (2013) 16 HKEC 139 (CA) para 15 (per $\mathrm{Ma}$ CJ).

$41 \quad$ Medical Council of Hong Kong v Chow Siu Shek David [2000] 2 HKC 428 438F.

42 Myburgh 2017 SALJ 519; Hutchinson 2017 SALJ 310. The perception of a retreat was not confined to South Africa. See Goddard and Johnson 2017 https://www.atkinchambers.com/wp-content/uploads/2017/02/ContractualInterpretation-Article-February-2017.pdf.

$43 \quad$ Arnold $v$ Britton [2016] 1 All ER 1 (SC) paras 15 to 23.

44 Rainy Sky SA v Kookmin Bank [2012] 1 All ER 1137 (SC) para 21 where Lord Clarke of Stone-under-Ebony said that: "... the exercise of construction is essentially one unitary exercise in which the court must consider the language used and ascertain what a reasonable person, that is a person who has all the background knowledge which would reasonably have been available to the parties in the situation in which they were at the time of the contract, would have understood the parties to have meant. In doing so, the court must have regard to all the relevant surrounding circumstances. If there are two possible constructions, the court is entitled to prefer the construction which is consistent with business common sense and to reject the other."

$45 \quad W o o d v$ Capita Insurance Services Ltd [2017] 4 All ER 615 (SC) paras 8-13. The method of interpretation that blends text and context is well-illustrated by the exposition of principle in the judgment of Lord Hodge in Barnardo's $v$ Buckinghamshire [2018] UKSC 55 paras 13-18 and the analysis in paras 19-29. 
contracts may be achieved by a greater emphasis on the factual matrix, for example because of their informality, brevity or the absence of skilled professional assistance. But negotiators of complex formal contracts may often not achieve a logical and coherent text because of, for example, the conflicting aims of the parties, failures of communication, differing drafting practices, or deadlines which require the parties to compromise in order to reach agreement. There may often therefore be provisions in a detailed professionally drawn contract which lack clarity and the lawyer or judge in interpreting such provisions may be particularly helped by considering the factual matrix and the purpose of similar provisions in contracts of the same type. The iterative process, of which Lord Mance spoke in Sigma Finance Corpn ... assists the lawyer or judge to ascertain the objective meaning of disputed provisions.

On this approach, the process of interpretation is no longer, assuming it once was, a war between textualism and contextualism. I venture to suggest that this does not differ materially from Endumeni. Both text and context have a role to play, and which will predominate will depend on the circumstances of each case.

\section{Text and context}

Let me expand briefly on the role of text and context. In a famous lecture Lord Steyn illustrated his well-known statement that "In law context is everything" 46 by reference to the story of Tamerlane, or Timur the Lame, the Turco-Mongolian emperor born in modern Uzbekhistan, when besieging the Turkish city of Sivas. The defending soldiers said they would surrender if he promised not to shed a drop of blood. Tamerlane agreed and then buried the soldiers alive, saying that he had kept his promise exactly. ${ }^{47}$

Lord Steyn used the story to illustrate his contention that literalism or, as we would now call it, textualism in the interpretation of legal documents is not a good thing. But classical tales do not point in only one direction and he overlooked an even more famous illustration drawn from Shakespeare's play The Merchant of Venice. The story is of a merchant, Antonio, who borrows money from the moneylender, Shylock. It is a thoroughly antiSemitic story, but that is not relevant to the point I want to make. As security Antonio had given a bond that, if he did not repay the debt, the moneylender might take a pound of flesh from his chest. Antonio's lawyer, Portia, pleaded for mercy, but when the plea fell on deaf ears she said, go ahead, your bond entitles you to your pound of flesh. And then she added: "But the bond says nothing about any blood. Take your pound of flesh, but if you spill a drop of

\footnotetext{
46 $\quad R v$ Secretary of State for the Home Department; Ex parte Daly [2001] 3 All ER 433 $(\mathrm{HL})$ para 28.

47 Steyn 1997 LQR 440-441.
} 
blood in doing so, you are in breach of the bond and will forfeit all your property". Shylock abandons his claim. A more successful invocation of the plain meaning of the text is hard to imagine.

This illustrates the point that sometimes language and syntax, and sometimes context, will predominate. Endumeni does away with the idea in Coopers \& Lybrand that interpretation is an exercise that occurs in stages. The starting point is the text, because as the writer Elena Ferrante expresses it: "The words, the grammar, the syntax are a chisel that shapes our thought." 48 But from the outset that is viewed in context, so that the process is both textual and contextual.

There will be some cases, though they are likely to be few, ${ }^{49}$ where the language admits of only one meaning, in which event no amount of reliance on context can avoid that meaning. In my experience, the ingenuity of counsel can usually find arguments favouring an alternative meaning, however unlikely they might seem in the light of the grammar and syntax of the provision under consideration. Then context will come into play to a greater or lesser extent. The clearer the language used in the text and the more obvious its meaning in accordance with the ordinary understanding of language, the less the influence of context in arriving at a conclusion as to its meaning. The more possible meanings there are and the more finely balanced they are, the more powerful will be the influence of contextual factors in the ultimate decision. In construing legislation or developing the common law the influence of the spirit, purport and objects of the Bill of Rights is an essential part of the context. ${ }^{50}$ But there is a line to be drawn beyond which the interpreter cannot go. Context cannot be used to create a meaning that the language, when viewed in context, is incapable of bearing. That is not interpretation. It is contractual or legislative drafting.

48 Ferrante 2018 https://www.theguardian.com/lifeandstyle/2018/feb/24/elenaferrante-on-italian-language-identity. The preceding sentence reads: "A language is a compendium of the history, geography, material and spiritual life, the vices and virtues, not only of those who speak it, but also of those who have spoken it through the centuries".

49 Commissioner, South African Revenue Service v Bosch 20152 SA 174 (SCA) para 9. As Lord Bingham said in Quintavalle such cases do not usually come before the courts and certainly not the higher courts. 


\section{The road ahead}

\subsection{Objective interpretation}

Some aspects of Endumeni have raised questions. The one relates to the notion that the process of interpretation is objective. This appears to have occasioned some uncertainty in academic minds, but I think that to the members of the judiciary it simply means that they are concerned with interpreting the language used in the document, be it contract or statute or whatever, and not trying to go behind it to any unwritten and unexpressed intention that the legislature or the parties may have had in formulating the document. In other words, it stands in contradistinction to the notion that the search is for a subjective intention of the legislature or the contracting parties not apparent from the words used in the document in the light of the relevant context. If the words have inaccurately expressed that intention, rectification is the mechanism to remedy this. The legislature can remedy omissions and misspeaking by way of amendment.

There are no great subtleties here and most judges and practitioners would be baffled by its description as "subjective objectivity", ${ }^{51}$ merely because the reader engages in interpretation in the light of context. The use of the word "objective" to describe the process merely reinforces the point that the court's task is to construe the language used in the contract or legislation and not to seek for unexpressed meanings discerned or, as Kentridge AJ once said, "divined" from other sources. In passing, I should perhaps say that this has very little to do with the fact that our law adopts a broadly subjective approach to the formation of contracts, that is, that they are created as a result of the agreement ("wilsooreenstemming") of the parties. ${ }^{52}$ Interpretation is the process that occurs after formation of the contract. It is overwhelmingly undertaken in relation to a written record of those prior actions and involves attributing meaning to a written text. It is not concerned with whether specific conduct creates a contract.

\subsection{Context in contract}

The next point is how a court addresses context. No hard and fast rule can be laid down in this regard because circumstances differ from case to case. But it makes no sense to treat the contracts of large commercial organisations such as banks as having been drafted to deal with specific factual circumstances, when one knows that they are generic contracts

$51 \quad$ Hutchinson 2017 SALJ 305 fn 21.

52 Saambou-Nasionale Bouvereniging v Friedman 19793 SA 978 (A) 993E-F. 
drafted to cover a variety of situations and taken out of the stationery cupboard by subordinate officials with little or no discretion to vary their terms. Standard form contracts are widely used in modern commerce, examples being sale or lease agreements, contracts of loan, insurance policies, arbitration agreements, bills of lading and charter-parties, construction contracts, deeds of suretyship and so on. These are referred to as contracts of adhesion ${ }^{53}$ because they are usually concluded on a "take it or leave it" basis, rather than as a result of a process of negotiation and agreement. To look at them as having a specific context arising from the identity or needs of the one individual contracting party rather than the organisation that caused the terms to be formulated is misleading. The purpose of the contract and the nature of the relationship it creates will be relevant, as will be the market in which it applies, but beyond that there is no meaningful fact-specific context. ${ }^{54}$ In interpreting such contracts the role of external facts to provide context is likely to be small.

The contracts of individuals and small businesses will often be different and less carefully formulated, especially where prepared by lay people. Here the likelihood of facts specific to the parties and their arrangements being relevant to the interpretation of the agreement is greater. Their contemplation will potentially have a greater impact. This emphasises the proposition that the more formal and careful the drafting, the less the need to look to extrinsic factors. Error is not lightly assumed, although that may not be the case where the evidence reveals that the contract was drafted in haste or by persons lacking legal training and drafting skills. Likewise superfluity is not assumed, but that is not to be confused with verbosity, which is ever present. Particular care must be taken by courts not to reverse the consequences of a hard-fought process of bargaining, or to relieve parties of risks that they decided to run in order to secure gains elsewhere.

In the result, in a detailed commercial contract the context will be provided largely by the nature and purpose of the transaction in question and the economic and commercial background to its conclusion. A loan from a bank is plainly different from a loan from a friend. Where there is disproportionate bargaining power, this must be recognised, as must the reasons for commercial organisations' wishing to standardise the terms of their business dealings with the general public. And, curiously enough, judges are human and reluctant to impose burdens that seem harsh and unfair on

$53 \quad$ See the discussion by Sachs $\mathrm{J}$ in Barkhuizen $v$ Napier 20075 SA 323 (CC) paras 135-139, 151-157.

$54 \quad$ Ledcor Construction Ltd v Northbridge Indemnity Insurance Co [2016] 2 SCR 23 paras $24,27-32$. 
the weaker and disadvantaged members of society. So fairness and equity is part of the context.

\subsection{Context in legislation}

When dealing with a statute, context does not involve guesswork as to the intention of the legislature, but a reasoned assessment of the broad purpose underlying its enactment. Statutes directed at ameliorating a distinct social problem are entitled to a more generous construction, given that purpose, ${ }^{55}$ than a technical regulatory statute such as the Companies Act. ${ }^{56}$ Nor can it mean, for example, that in a taxing statute a construction favourable to the revenue must be given because the purpose of the statute is to raise revenue. But anti-avoidance measures may be entitled to more generous consideration than the provisions defining what is taxable.

In a recent minority judgment in the $\mathrm{SCA}^{57}$ the application to legislation of the interpretational approach in Endumeni is questioned. It relies on the distinction drawn in modern linguistic philosophy between sentence meaning - the meaning of the words in the text - and speaker meaning the meaning that can be attributed to the speaker of those words by an examination of the context and the circumstances which gave rise to the document. The point is pertinently and correctly raised that there is a fundamental difference between the process by which a contract comes into force, either as a result of negotiation between bargaining parties, or by adhesion in consequence of the weaker bargaining party's need for the goods or services supplied, and the legislative process. From this it is suggested that context is fact specific and "can be applied to the interpretation of contracts and like documents, but not of statutes".

The approach strikes me as unusual, for courts here and elsewhere have repeatedly claimed that they had regard to context in construing statutes. ${ }^{58}$ The so-called "mischief" rule, where the court construes the language against the background of the perceived mischief that the statute addresses, is an obvious example. Where a statute is the product of a commission of enquiry it is permissible for a court to have regard to the report of the commission to ascertain the mischief at which the legislation

\footnotetext{
$55 \quad$ Looyen v Simmer \& Jack Mines Ltd 19524 SA 547 (A) 554; Slims (Pty) Ltd v Morris 19881 SA 715 (A) 734.

$56 \quad$ Companies Act 73 of 2008.

$57 \quad$ CSARS v Daikin Air Conditioning 2018 ZASCA 66 (25 May 2018) paras 31-35.

58 Glazebrook 2003 https://www.courtsofnz.govt.nz/speechpapers/Speech05-052003.pdf.
} 
was aimed and the view then held of the existing state of the law. ${ }^{59}$ The explanatory memorandum prepared by the committee that drafted the Labour Relations Act 66 of $1995^{60}$ has been referred to on countless occasions as providing relevant context to the provisions of the LRA. ${ }^{61}$

Then there is the context provided by the content of the legislation as a whole. This is invariably relevant because of the provision in the definition section of all statutes that the definitions will apply "unless the context otherwise indicates". This provision was considered by the SCA in Hoban ${ }^{62}$ where it was described in the following way:

\begin{abstract}
'Context' includes the entire enactment in which the word or words in contention appear ... and in its widest sense would include enactments in pari materia and the situation, or 'mischief', sought to be remedied. ... That is the first point. The second is that there is no justification for the distinction, so heavily relied on by the learned Judge, between linguistic context and legislative intention. The moment one has to analyse context in order to determine whether a meaning is to be given which differs from the defined meaning one is immediately engaged in ascertaining legislative intention. One remains so engaged until the interpretation process is concluded. It is only concluded when legislative intention is established. As remarked by $\mathrm{E}$ Cameron in Joubert (ed) The Law of South Africa vol 27 at 207 para 229,'... 'context does no more than reflect legislative meaning which in turn is capable of being expressed only through words in context'.
\end{abstract}

Legislative history is another source of relevant context that can be of great assistance in resolving problems of interpretation and can on occasions prove decisive in clarifying what is otherwise obscure. ${ }^{63}$ The provisions of the Interpretation Act 33 of 1957 operate as interpretative guides in certain situations, and finally section 39(2) of the Constitution contains the injunction that legislation must be interpreted in accordance with the spirit, purport and objects of the Bill of Rights. So, as with all law, the Constitution provides a context for its interpretation that cannot be avoided and will plainly affect the meaning of specific provisions, even though its terms may not specifically address the problem under consideration. It provides the norms by and through which the interpretative process is undertaken.

Looking at another field, that straddles those of legislation and contract, or more accurately agreement in the broad sense, because we are not dealing with contractually enforceable undertakings, the approach to the

$59 \quad$ Westinghouse Brake \& Equipment (Pty) Ltd v Bilger Engineering (Pty) Ltd 19862 SA 555 (A) 562A-563A.

$60 \quad$ Ministerial Task Team 1995 ILJ 278.

61 See, for example Sidumo v Rustenburg Platinum Mines Ltd 20082 SA 24 (CC) para 94, fn 100

$62 \quad H o b a n v$ Absa Bank Ltd t/a United Bank 19992 SA 1036 (SCA) para 20.

63 Santam Insurance Ltd v Taylor 19851 SA 514 (A) 526-527B. 
construction of treaties in the form of Articles 31 and 32 of the Vienna Convention ${ }^{64}$ requires them to be interpreted "in good faith in accordance with the ordinary meaning to be given to the terms of the treaty in their context and in the light of their object and purpose". If international agreements are to be construed in the light of context, it is legitimate to ask why domestic legislation should lack context for the purposes of interpretation. Context in the form of the travaux preparatoires and other material such as historical background is used to interpret treaties, whether free standing or, as is required in South Africa, by section 231(2) of the Constitution after it has been adopted into domestic law. There are several statutes incorporating such conventions into domestic law: for example, the Carriage by Air Act 17 of 1946, incorporating by section 3 thereof the provisions of the Montreal Convention, in the form of the schedule to the statute, and the Carriage of Goods by Sea Act 1 of 1986, making the provisions of the Hague-Visby Rules applicable to the carriage of goods from South African ports. Although South Africa is not a party to the Vienna Convention, section 233 of the Constitution requires courts where possible to construe all law in accordance with international law.

While I am hesitant to become involved in the field of linguistic philosophy, where others may feel more at home than I, it seems to me that the notion of speaking meaning ${ }^{65}$ may apply differently and possibly with greater force and effect in the context of conversation and the human interactions that characterise conversation, than when interpreting written texts. Importantly, it serves the purpose of identifying how in conversation externalities outside the words used by the speaker contribute to the hearer's understanding of what is said. In the context of written texts, the same is true, but the nature of the externalities that contribute to understanding will vary from instance to instance. The nature of the document and its purpose, i.e. whether it sets rules to govern a relationship in the case of contract or rules to govern society in the case of legislation, provide an important part of those externalities.

So, while I agree that the manner in which a court determines the meaning of a statute will differ from the manner in which it will approach a contract, ${ }^{66}$

$64 \quad$ Vienna Convention on the Law of Treaties (1969). The definition of a treaty in Art 1 (a) of the Convention makes it plain that it includes both treaties and conventions that have entered into force.

65 First articulated, as I understand it, by Paul Grice, although he used the expression "conversational implicature". See Grandy and Warner 2017 https://plato.stanford.edu/archives/win2017/entries/grice/. CSARS v Daikin Air Conditioning 2018 ZASCA 66 (25 May 2018) para 33. 
that is not - it seems to me - because legislation lacks a speaker meaning, but because the nature and purpose of the document and the relevant context are different. It does not, I think, undermine the basic point of Endumeni that text and context go together in the process of interpretation; that one starts with the language and the rules of grammar and syntax, but always viewed in the light of the context, the apparent purpose of the document and, where there is relevant knowledge, the material known to those responsible for its coming into existence. This is not confined to contracts. Even legislators and the officials who are initially responsible for the drafting of legislation are aware of external facts that lead to legislation being passed.

\subsection{Sense and sensibility}

One other point worth mentioning is that Endumeni is not an invitation to judges to impose their life experience on the parties or the statutory material. Context must be apparent from the material placed before the court or matters in regard to which it is legitimate to take judicial notice, that is, matters of relatively common knowledge. That is as true of knowledge of commercial matters as it is of the history and problems of society and anything else coming before a court of law. So in making use of context the judge must be sure that the context on which reliance is to be placed is of this character, not a matter of personal belief, experience, predilection or prejudice.

Let me deal in greater detail with commercial sensibility. That is an expression to be found in the English judgments, which focus particularly on commercial contracts. It is not an expression used in Endumeni. What I said was that a sensible construction was to be preferred to one that was insensible or unbusinesslike. And provided judges heed the warning that followed, that it is not for them to impose their personal sense of what would be sensible or desirable in place of what the parties to the contract or the legislative body have actually said, this should not be problematic.

When one speaks of preferring a sensible result to an insensible one, the standard is not one that is personal to the views of the judge. Instead it is far more general and involves a broader assessment of what would be regarded as sensible by society in that situation. In the case of legislation the temptation is to supplement what the legislature has said with what the 
judge thinks it should have said. Wilson CJ pointed out the fallacy in this a century ago, in Richardson $v$ Austin, in the following terms: ${ }^{67}$

\begin{abstract}
$\ldots$ as to the argument from the assumed intention of the legislature, there is nothing more dangerous and fallacious in interpreting a Statute than first of all to assume that the legislature had a particular intention, and then, having made up one's mind what that intention was, to conclude that that intention must necessarily be expressed in the Statute, and then proceed to find it.
\end{abstract}

When one speaks of a contract being unbusinesslike, the danger of course lies in failing to resist the temptation to rescue one party from the consequences of a bad bargain, but I would have thought that it was clear that this is not the judicial role. Judges can do a lot to ensure fairness in society, but they do so within the framework we call the law and their room for manoeuvre is not unlimited. So avoiding an unbusinesslike result addresses the likelihood that reasonable persons would not commit themselves to a contractual relationship that holds benefit only to one side and disadvantage only to the other. Of course, there are contracts where that is so and, within the bounds of public policy, the courts must enforce them. ${ }^{68}$ But in the ordinary course most contracts are concluded on a basis that appears to hold out benefits to both sides of the relationship, so it is legitimate to construe them with that in mind.

\title{
7 Conclusion
}

What are the underlying principles that animate the judgment in Endumeni? The first is that we need to escape from an approach to interpretation that involves an a priori assessment of the meaning of the document in issue and then an endeavour, by invoking whichever canons of interpretation suit, to justify that meaning. It serves as a check on the tendency, to which we are all prey, to reason backwards from a desired or a priori conclusion to the justification for that conclusion.

Endumeni demands of judges that they articulate their reasons, both linguistic and contextual, for arriving at their decisions on questions of the construction of documents. As such it should produce greater transparency in regard to judicial decision-making in this sphere. Once judges treat it as second nature to explain the contextual material on which they rely, it will be possible to assess whether that reliance is legitimate or unjustified. It will enable the litigants and appellate courts to determine whether that material

67 Richardson v Austin (1911) 12 CLR 463 470. See also see Lewison Interpretation of Contracts para 2.06 for similar statements. Bishop and Brickhill 2012 SALJ 681 have suggested that the Constitutional Court has been guilty of the same fault. 
was properly before the judge and whether it provided a complete picture from which it was permissible to draw the conclusions in question.

The second animating principle is that it is desirable to have a single reasonably clear standard for the interpretation of documents that enables lawyers and courts to go about their business of interpreting documents, without becoming bogged down in the "how" of interpretation.

There are areas of interpretation that are untouched by the contents of this paper, which has concentrated on contracts and statutes, rather than other areas of law. Perhaps the most obvious omission is the fertile field of the construction of wills and the extent to which the Endumeni approach to interpretation can be adapted to that situation. ${ }^{69}$ That is a particular omission, given that in articulating his golden rule Lord Wensleydale specifically said that it applied to "wills and, indeed statutes and all written instruments". Wills are of course unilateral documents, but so are statutes, patent specifications and judgments, yet they all demand a broadly similar approach. But the field is special and encumbered by a considerable number of terms and concepts that are technical and have a special meaning deserving of lengthier and more detailed consideration than is feasible in this article.

Lastly, to those who may think it is their academic obligation to pore over this paper to discern new approaches, or detect a retreat from previous standpoints, may I implore them to approach the task with the following understanding, namely, that: ${ }^{70}$

Interpretation is the process of attributing meaning to the words used in a document, ... having regard to the context provided by reading the particular provision or provisions in the light of the document as a whole and the circumstances attendant upon its coming into existence. Whatever the nature of the document, consideration must be given to the language used in the light of the ordinary rules of grammar and syntax; the context in which the provision appears; the apparent purpose to which it is directed and the material known to those responsible for its production. Where more than one meaning is possible each possibility must be weighed in the light of all these factors. The process is objective not subjective. A sensible meaning is to be preferred to one that leads to insensible ... results or undermines the apparent purpose of the document. ... [B]e alert to, and guard against, the temptation to substitute what [you] regard as reasonable [or] sensible for the words actually used [for] to do so is to cross the divide between interpretation and [divination].... The 'inevitable point of departure is the language ... itself', read in context and

$69 \quad$ In Raubenheimer $v$ Raubenheimer 20125 SA 290 (SCA) para 21 the court applied contractual principles governing the implication of terms in contracts to the implication of a term in a will. 
having regard to [its] purpose ... and the background to the preparation and production of [this] document.

\section{BIBLIOGRAPHY}

\section{Literature}

Barber 2016 VUWLR

Barber M "The Contractual Interpretation of Tipping J" 2016 VUWLR 227244

Bishop and Brickhill 2012 SALJ

Bishop $M$ and Brickhill $J$ "'Ín the Beginning was the Word': The Role of Text in the Interpretation of Statutes" 2012 SALJ 681-716

Driedger Construction of Statutes

Driedger EA Construction of Statutes $2^{\text {nd }}$ ed (Butterworth Toronto 1983)

Hutchinson 2017 SALJ

Hutchinson D "Relational Theory, Context and Commercial Common Sense: Views on Contract Interpretation and Adjudication" 2017 SALJ 296326

Jansen 1981 TSAR

Jansen EL "Uitleg van Kontrakte en die Bedoeling van die Partye" 1981 TSAR 97-104

Lewison Interpretation of Contracts

Lewison $\mathrm{K}$ The Interpretation of Contracts $5^{\text {th }}$ ed (Sweet and Maxwell London 2011)

Ministerial Task Team 1995 ILJ

Ministerial Task Team "Explanatory Memorandum to the Draft Labour Relations Bill, 1995" 1995 ILJ 278-336

Myburgh 2017 SALJ

Myburgh F "Thomas Kuhn's Structure of Scientific Revolutions, Paradigm Shifts and Crises: Analysing Recent Changes in the Approach to Contractual Interpretation in South African Law" 2017 SALJ 514-542

Shakespeare As You Like It

Shakespeare W As You Like It (Penguin Classics London 2015) 
Spigelman 2007 ALJ

Spigelman CJ "From Text to Context: Contemporary Contractual Interpretation" 2007 ALJ 322-333

Steyn $1997 L Q R$

Steyn $\mathrm{J}$ "Contract Law: Fulfilling the Reasonable Expectations of Honest Men" 1997 LQR 433-441

Steyn Uitleg van Wette

Steyn LC Die Uitleg van Wette $3^{\text {rd }}$ ed (Juta Cape Town 1968)

\section{Case law}

Airports Company South Africa v Big Five Duty Free (Pty) Ltd 20192 BCLR 165 (CC)

Aktiebolaget Hässle v Triomed (Pty) Ltd 20031 SA 155 (SCA)

Arnold v Britton [2016] 1 All ER 1 (SC)

Barkhuizen v Napier 20075 SA 323 (CC)

Barnardo's v Buckinghamshire [2018] UKSC 55

Bastian Financial Services (Pty) Ltd v General Hendrik Schoeman Primary School 20085 SA 1 (SCA)

Bato Star Fishing (Pty) Ltd v Minister of Environmental Affairs 20044 SA 490 (CC)

Bothma-Batho Transport (Edms) Bpk v S Bothma \& Seun Transport (Edms) Bpk 20142 SA 494 (SCA).

Byrnes v Kendle (2011) 243 CLR 253

Chartbrook Ltd v Persimmon Homes Ltd [2009] UKHL 38

Codelfa Construction Pty Ltd $v$ State Rail Authority of New South Wales (1982) 149 CLR 337

Commissioner, South African Revenue Service v Bosch 20152 SA 174 (SCA)

Cool Ideas 1186 CC v Hubbard 20144 SA 474 (CC) 
Coopers \& Lybrand v Bryant 19953 SA 761 (A)

Crispette and Candy Co Ltd v Oscar Michaleis and Leopold Alexander Michaelis 19474 SA 521 (A)

CSARS v Daikin Air Conditioning 2018 ZASCA 66 (25 May 2018)

Department of Land Affairs v Goedgelegen Tropical Fruits (Pty) Ltd 20076 SA 199 (CC)

Ekurhuleni Metropolitan Municipality v Germiston Municipal Retirement Fund 20102 SA 498 (SCA)

Electricity Generation Corporation v Woodside Energy Ltd 251 CLR 640 $(\mathrm{HCA})$

Firm PI 1 Ltd v Zurich Australian Insurance Ltd [2015] NZLR 432

Fully Profit (Asia) Ltd v Secretary for Justice (2013) 16 HKEC 139 (CA)

Grey v Pearson $6 \mathrm{H}$ L Cas 106

Hoban v Absa Bank Ltd t/a United Bank 19992 SA 1036 (SCA

Investors Compensation Scheme Ltd $v$ West Bromwich Building Society (ICS) [1998] 3 All ER 98 (HL)

Jaga v Dönges; Bhana v Dönges 19504 SA 653 (A)

Jumbo King Ltd v Faithful Properties Ltd (1999) 3 HKLRD 757 (CFA)

Kalil v Standard Bank of South Africa Ltd 19674 SA 550 (A)

KPMG Chartered Accountants (SA) v Securefin Ltd 20094 SA 399 (SCA)

Ledcor Construction Ltd v Northbridge Indemnity Insurance Co [2016] 2 SCR 23

Looyen v Simmer \& Jack Mines Ltd 19524 SA 547 (A)

Masstores (Pty) Ltd v Murray \& Roberts Construction (Pty) Ltd 20086 SA 654 (SCA)

Medical Council of Hong Kong v Chow Siu Shek David [2000] 2 HKC 428

Melmoth Town Board v Marius Mostert (Pty) Ltd 19843 SA 718 (AD) 
Minister of Justice and Constitutional Development v Masingili 20141 SACR 437 (CC)

Nederduitse Gereformeerde Kerk in Afrika (OVS) v Verenigende Gereformeerde Kerk in Suider-Afrika 19992 SA 156 (SCA)

Natal Joint Municipal Pension Fund v Endumeni Municipality 20124 SA 593 (SCA)

Novartis SA (Pty) Ltd v Maphil Trading (Pty) Ltd 20161 SA 518 (SCA)

Pepper v Hart [1993] 1 All ER 42 (HL)

Prenn v Simmons [1971] 3 All ER $237(\mathrm{HL})$

Principal Immigration Officer v Hawabu 1936 AD 2631

$R v$ Cain 19593 SA 376 (A)

$R v$ Sisilane 19582 SA $448(\mathrm{~A})$

$R$ (Quintavalle) v Secretary of State for Health [2003] 2 AC 687

$R v$ Secretary of State for the Home Department; Ex parte Daly [2001] 3 All ER $433(\mathrm{HL})$

Rainy Sky SA v Kookmin Bank [2012] 1 All ER 1137 (SC)

Raubenheimer v Raubenheimer 20125 SA 290 (SCA)

Richardson v Austin (1911) 12 CLR 463

Rizzo \& Rizzo Shoes Ltd (Re) [1998] 1 SCR 27 (SCC)

S v Dhlamini 19741 SA $90(\mathrm{~A})$

S v Makwanyane 19953 SA 391 (CC)

Saambou-Nasionale Bouvereniging v Friedman 19793 SA 978 (A)

Santam Insurance Ltd v Taylor 19851 SA 514 (A)

Sattva Capital Corporation (Formerly Sattva Capital Inc v Cresston Moby Corporation (Formerly George Ventures Inc) [2014] SCR 633

Sidumo v Rustenburg Platinum Mines Ltd 20082 SA 24 (CC) 
Slims (Pty) Ltd v Morris 19881 SA 715 (A)

Summit Industrial Corporation v Claimants against the Fund Comprising the Proceeds of the Sale of the MV Jade Transporter 19872 SA 583 (A)

Swart v Cape Fabrix (Pty) Ltd 19791 SA 195 (A)

Van der Westhuizen v Arnold 20026 SA 453 (SCA)

Vector Gas Ltd v Bay of Plenty Energy Ltd [2010] NZSC 5; [2010] 2 NZLR 444

Western Export Services Inc v Jireh International Pty Ltd (2011) 282 ALR 804 (HCA)

Westinghouse Brake \& Equipment (Pty) Ltd v Bilger Engineering (Pty) Ltd 19862 SA 555 (A)

Wood v Capita Insurance Services Ltd [2017] 4 All ER 615 (SC)

Zurich Insurance (Singapore) Pte Ltd $v$ B-Gold Interior Design \& Construction Pte Ltd [2008] 3 SLR (R) 1029

\section{Legislation}

Carriage by Air Act 17 of 1946

Carriage of Goods by Sea Act 1 of 1986

Constitution of the Republic of South Africa, 1996

Criminal Procedure Act 56 of 1955

Criminal Procedure Act 51 of 1977

Companies Act 73 of 2008

Interpretation Act 33 of 1957

Labour Relations Act 66 of 1995

Malaysian Interpretation Acts 1948 and 1967

New Zeeland Interpretation Act 85 of 1999

Singapore Interpretation Act 10 of 1965 


\section{International instruments}

Hague-Visby Rules (1924)

Montreal Convention (1999)

Vienna Convention on the Law of Treaties (1969)

\section{Internet sources}

Ferrante 2018 https://www.theguardian.com/lifeandstyle/2018/feb/24/ elena-ferrante-on-italian-language-identity

Ferrante E 2018 Yes, I'm Italian - but l'm not Loud, I don't Gesticulate and I'm not Good with Pizza https://www.theguardian.com/lifeandstyle/ 2018/feb/24/elena-ferrante-on-italian-language-identity accessed 10 October 2019

Glazebrook $2003 \quad$ https://www.courtsofnz.govt.nz/speechpapers/ Speech05-05-2003.pdf

Glazebrook S 2003 Filling the Gaps https://www.courtsofnz.govt.nz/ speechpapers/Speech05-05-2003.pdf accessed 20 June 2018

Goddard and Johnson 2017 https://www.atkinchambers.com/wpcontent/uploads/2017/02/Contractual-Interpretation-Article-February2017.pdf

Goddard A and Johnson D 2017 Contractual Interpretation - The Retreat from Hoffmann https://www.atkinchambers.com/wp-content/ uploads/2017/02/Contractual-Interpretation-Article-February-2017.pdf accessed 20 June 2018

Grandy and Warner 2017 https://plato.stanford.edu/ archives/win2017/entries/grice/

Grandy RE and Warner R 2017 Paul Grice - The Stanford Encyclopedia of Philosophy https://plato.stanford.edu/archives/win2017/entries/grice/ accessed 20 June 2018

McDougall 2015 http://www.supremecourt.justice.nsw.gov.au/Documents/ Publications/Speeches/2015\%20Speeches/McDougall_20150626.pdf McDougall R 2015 Construction of Contracts: The High Court's Approach http://www.supremecourt.justice.nsw.gov.au/Documents/Publications/Spe eches/2015\%20Speeches/McDougall_20150626.pdf accessed 19 June 2018 
Menon 2013 http://www.supremecourt.gov.sg/docs/default-source/defaultdocument-library/sjc/the-interpretation-of-documents---saying-what-theymean-or-meaning-what-they-say.pdf

Menon S 2013 The Interpretation of Documents: Saying what they mean or Meaning what they Say http://www.supremecourt.gov.sg/docs/defaultsource/default-document-library/sjc/the-interpretation-of-documents--saying-what-they-mean-or-meaning-what-they-say.pdf accessed 20 June 2018

Middleton 2016 http://www.fedcourt.gov.au/digital-law-library/judgesspeeches/justice-middleton/middleton-j-20160414 Middleton J 2016 Statutory Interpretation - Mostly Common Sense? Melbourne University Law Review Annual Lecture http://www.fedcourt.gov.au/digital-law-library/judges-speeches/justicemiddleton/middleton-j-20160414 accessed 19 June 2018

Rajah 2010 http://www.malaysianbar.org.my/index.php?option=com_ docman\&task $=$ doc_view\&gid $=2705$

Rajah VK 2010 Redrawing the Boundaries of Contractual Interpretation: From Text to Context to Pre-Text and beyond http://www.malaysianbar.org.my/index.php?option=com_docman\&task=do c_view\&gid=2705 accessed 20 June 2018

\section{List of Abbreviations}

ALJ

ILJ

LQR

LRA

SALJ

SCA

TSAR

VUWLR
Australian Law Journal

Industrial Law Journal

Law Quarterly Review

Labour Relations Act 66 of 1995

South African Law Journal

Supreme Court of Appeal

Tydskrif vir die Suid-Afrikaanse Reg

Victoria University of Wellington Law Review 